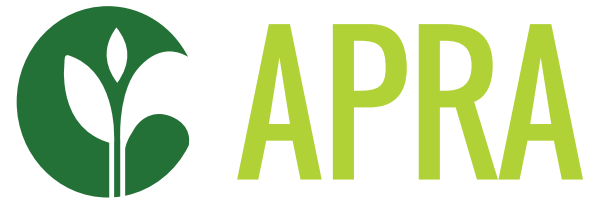

Agricultural Policy Research in Africa
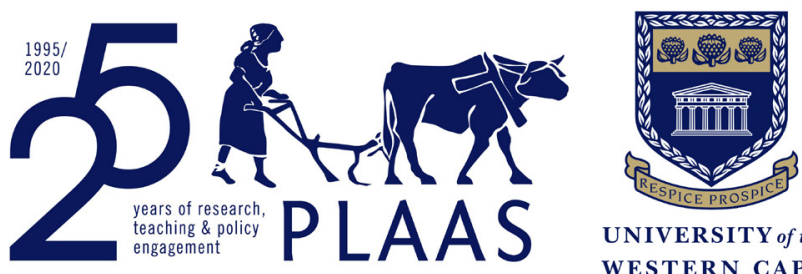

UNIVERSITY of the WESTERN CAPE

\title{
AGRICULTURAL INVESTMENT CORRIDORS IN AFRICA: DOES SMALLHOLDER AND WOMEN'S PARTICIPATION COUNT?
}

Rebecca Smalley, Emmanuel Sulle, Ngala Chome, Ana Duarte and Euclides Gonçalves 


\section{CONTENTS}

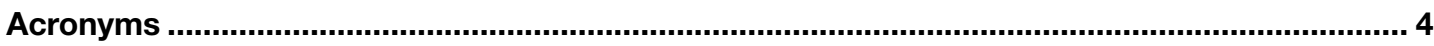

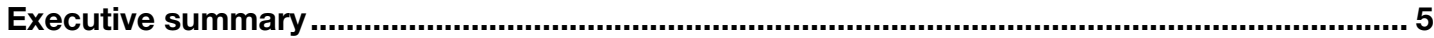

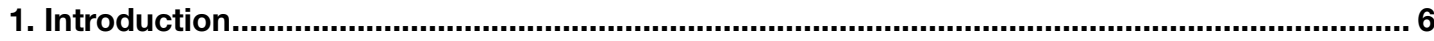

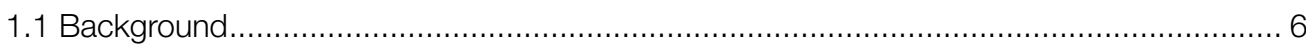

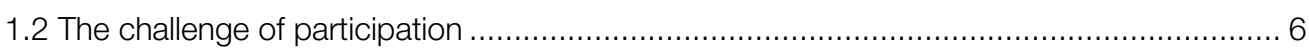

2. Methodology

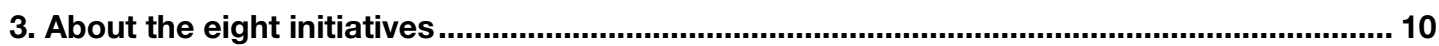

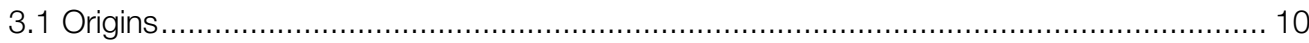

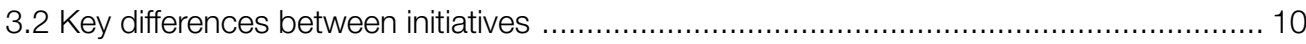

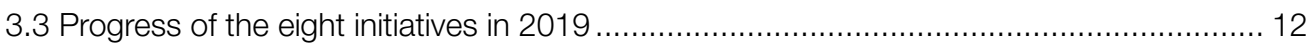

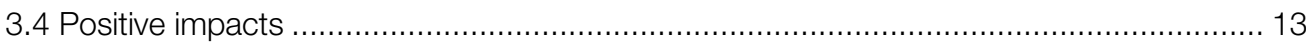

3.5 Constraints on wider benefits for smallholders and women......................................... 13

4. Smallholder and women's group engagement in the eight cases....................................... 15

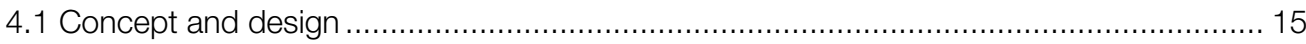

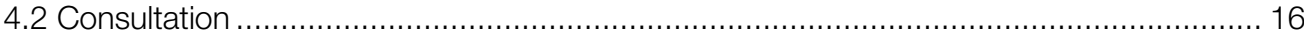

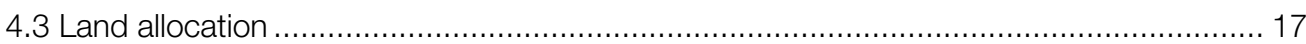

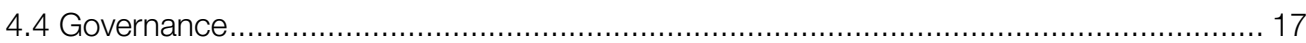

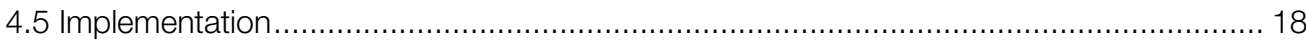

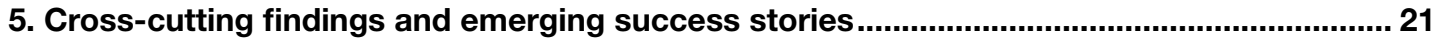

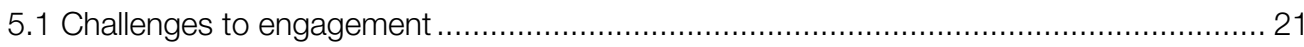

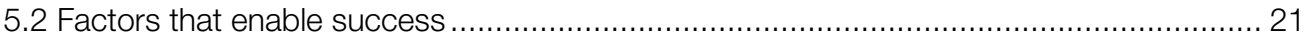

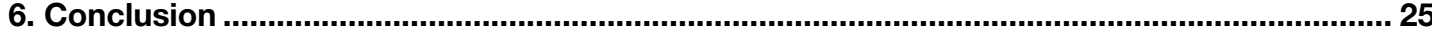

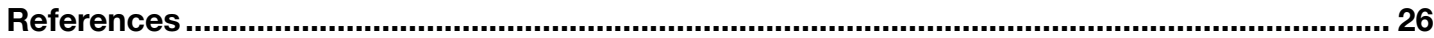

\section{List of tables}

Table 5.1 Policies that enable engagement of smallholders and women's groups ................. 22

\section{List of figures}

Figure 2.1 Locations of the five corridors studied in depth ................................................... 9

Figure 3.1. Key differences between the eight development initiatives ................................. 11 


\section{ACKNOWLEDGEMENTS AND DISCLAAIMER}

This Working Paper presents research that was conducted in 2018 and 2019. It does not take into account any material or strategic changes that have been made with regard to the development initiatives since then. Nor does it consider any politico-economic changes in the development regions or any organisational changes in the stakeholder landscape since 2019.

Many of the research findings are based on the authors' interpretation of documentary sources. Interviews were also conducted, but this varied from initiative to initiative, and it was not possible to reach representatives of LAKAJI, Bagré Growth Pole or WBNLDC. Therefore, the findings of this Working Paper are limited by the availability of documentation, and by the small number of respondent interviews for triangulating or countering observations from the documentary sources.

The authors thank the many stakeholders and experts interviewed remotely and during fieldwork in Angola, Kenya, Mozambique and Tanzania for the research. The research team also appreciate the feedback given by Ruth Hall, lan Scoones and an anonymous internal reviewer.

Rebecca Smalley is a PhD candidate in Applied Economics and Marketing in the School of Agriculture Policy and Development at the University of Reading, UK. Emmanuel Sulle is a PhD Candidate in Land and Agrarian Studies at the Institute for Poverty, Land and Agrarian Studies (PLAAS), University of the Western Cape, South Africa. Ngala Chome holds a PhD from Durham University, UK. Ana Duarte is a Lecturer in the Department of Economics of Lusíada University, Angola, where she is also a Director. She holds a PhD in Development Studies from the School of Oriental and African Studies, University of London, UK. Euclides Gonçalves is a director and researcher at Kaleidoscopio - Research in Public Policy and Culture, an independent research institution based in Maputo, Mozambique.

This working paper is funded with UK aid from the UK government (Foreign, Commonwealth \& Development Office - FCDO, formerly DFID). The opinions are the authors' and do not necessarily reflect the views or policies of IDS or the UK government 


\section{ACRONYMS}

AfDB

BAGC

CIRAD

DFID

IFC

IUCN

JICA

LAKAJI

LAPSSET

NGO

SAGCOT

SIDA

SME

USAID

WBNLDC
African Development Bank

Beira Agricultural Growth Corridor

French agricultural research and cooperation organization

United Kingdom Department for International Development, replaced in 2020 by the Foreign, Commonwealth \& Development Office

International Finance Corporation

International Union for Conservation of Nature

Japan International Cooperation Agency

Lagos-Kano-Jibiya Agricultural Growth Corridor

Lamu Port-South Sudan-Ethiopia Transport Corridor

non-governmental organisation

Southern Agricultural Growth Corridor of Tanzania

Swedish International Development Agency

small and medium-sized enterprise

United States Agency for International Development

Walvis Bay-Ndola-Lubumbashi Development Corridor 
Agricultural development corridors and clusters are highly complex projects that have been driven in Africa by agribusiness and mining corporations, host governments, international donors and development finance institutions. There is interest in whether these projects can support inclusive agribusiness. Evidence shows that involvement of small-scale economic actors in such initiatives is often impeded by a failure to grant them participation or a voice. We therefore investigated if and how recent corridors and clusters in Africa have been able to achieve the meaningful engagement of smallscale economic actors, with a focus on smallholders, including pastoralists, and the women among them. Eight initiatives were studied during the period 2018-19: Lamu Port-South Sudan-Ethiopia Transport Corridor in Kenya; Southern Agricultural Growth Corridor of Tanzania; Nacala Corridor in Mozambique and Malawi, incorporating the ProSAVANA agricultural development programme; Beira Agricultural Growth Corridor in Mozambique and Zambia; Lagos-Kano-Jibiya Agricultural Growth Corridor in Nigeria; Bagré Growth Pole in Burkina Faso; Lobito Corridor in Angola, linking to Democratic Republic of Congo and Zambia; and Walvis Bay-Ndola-Lubumbashi Development Corridor in Namibia, Zambia and Democratic Republic of Congo.

Based on a review of the literature and interviews with experts, we observed that smallholder and women's organisations were rarely invited to contribute to the conception and design of the corridor and growth pole projects and are only minimally involved in their governance. As the projects have unfolded, land rights abuses have occurred and some poorly designed support programmes were initiated. However, we document attempts at engagement of smallholders during phases of consultation, land allocation and project implementation.

Challenges to increasing and deepening their engagement include a lack of effective organisations to represent small-scale producers and businesses; inadequate structures for information-sharing, monitoring and accountability; some incorrect assumptions and biases; overly centralised planning and decision-making; and the need for project planners to address the commercial needs of privatesector investors.
We find that the prospects of smallholder and women's group inclusion are better in demand-driven initiatives and/or initiatives that are strongly influenced by donors or development partners which prioritise smallholder infrastructure or value chain programmes with access to financing; and that are not strongly influenced by agribusiness firms whose strategic priorities include large-scale land acquisition or commodity extraction.

The report identified a systematic lack of engagement of smallholders and small-scale businesspeople in the concept and design stage of spatial development initiatives. The resulting development visions are not always appropriate to a smallholder context, but there are ways - both deliberate and unintended - in which the extent of investment in large-scale farms and plantations can be lessened.

Project managers, governments, donors and lenders can take measures to improve the engagement of smallholders and women. For example, they can build the capacity of farmers' and women's organisations to participate in decision-making structures and set quotas for their inclusion in governance bodies. Governments and lenders can introduce requirements for smallholder inclusion and gender-sensitive approaches as conditions and selection criteria for agricultural investments, farmer training and value chain programmes, while project managers can establish communications and monitoring procedures. Overall, the managers of corridor and growth pole projects must learn the lessons from past initiatives and begin dialogues with small-scale agricultural actors as soon as possible in the development process.

Corridors and growth poles have been shaped not only by external forces, but also by local politics, dynamics and confrontations among actors. Outside formal structures, smallholders and women have forced an increase in their engagement through activism and resistance. These energies can be amplified and channeled by neutral third parties. Too often, non-governmental organisation (NGO) programmes have been limited, but effective civil society can help to mediate between stakeholders and develop innovative ways in which the voices of smallholders and women can be heard. On this basis, we find that including smallholders, pastoralists and women from the outset of these initiatives is central to ensure successful implementation, monitoring and evaluation of their outcomes. 


\section{INTRODUCTION}

\subsection{Background}

This Working Paper presents findings from qualitative research on recent development corridors and agribusiness clusters in sub-Saharan Africa. These corridors and clusters are large-scale initiatives which are aimed at improving business, trade and agriculture through public-sector funding and private capital. The clusters, known as growth poles in West Africa, focus on agricultural production and agribusiness linkages. Corridors tend to have a wider remit, often involving the extractives and transport industries, but may also be designed with agricultural development in mind. Both corridors and clusters usually include investment in hard infrastructure, such as roads or irrigation infrastructure, and in soft infrastructure and skills, such as farmer training, building commercial relationships between actors in a supply chain or simplifying border crossings.

From a development perspective, corridors and clusters or growth poles are conceived so that local smallholders and small businesses will come into closer proximity with larger companies. Corridors are expected to link local farmers and businesspeople to national or international markets, while agricultural clusters or growth poles are intended to create local hubs where large farms will generate positive spillover effects and commercial actors up- and downstream ${ }^{1}$ will create more business opportunities.

If designed correctly, therefore, corridors and clusters or growth poles are intended by their proponents to promote inclusive agribusiness in Africa. Achieving agribusiness that is inclusive of low-income and marginalised groups has become a major priority for donors and international finance institutions (Woodhill, 2016; Chamberlain and Anseeuw, 2019). Small-scale family operations, or smallholdings, predominate in African agriculture (Christiaensen and Demery, 2017), and women are critical to smallholder production: they are estimated to provide 40 per cent of all labour in crop farming in six African countries, and 52 per cent just in Tanzania, one of the countries in this present study (Palacios-Lopez, Christiaensen and Kilic, 2017). ${ }^{2}$ However, critical observers point to barriers that sometimes prevent smallholders and women from sustained participation in the potentially lucrative markets promoted by corridors and clusters. One large barrier to inclusion is that smallholders and women may be excluded from having a voice in the design and governance of public-private partnerships and spatial development initiatives (Fairtrade Foundation, 2014; Oxfam Novib, 2015).

This research study therefore investigated if and how recent corridors and clusters have been able to achieve the participation of smallholders, including livestock keepers and pastoralists, and women in particular. ${ }^{3}$ The aim of this study was to identify common challenges and pitfalls, and to highlight key lessons that could be shared with organisations involved in spatial development initiatives in Africa to enhance their prospects for long-term stability and effectiveness.

\subsection{The challenge of participation}

'Participation' is a loaded term which can be used to describe various degrees of involvement (Hickey and Mohan, 2004). Tanwir and Safdar (2013) note that some authors describe participation as a spectrum from low to high, such as Agarwal's spectrum from 'nominal' to 'empowering' participation, and Cornwall's spectrum from 'functional' to 'transformative' participation. Like Agarwal and Cornwall, Tanwir and Safdar argue that people's - particularly women's - participation in development projects should be empowering and transformative. Fairtrade Foundation (2014) use the alternative term 'engagement' to describe all instances of involvement by people in public-private partnerships in agriculture. They agree that the process should be empowering, but their ultimate goal is not participation but ownership.

When it comes to long-term and large-scale spatial development initiatives such as corridors or growth poles, an important potential area of engagement is in the governance of the initiative. 'Governance' here describes the system of decision-making and oversight of implementation, information dissemination and relationship-building involved in the development initiative (Schut, Soares, van de Ven and Slingerland, 2014; Vogelsperger, Lakoussan and Teshome, 2017). Some authors note that governance of these initiatives includes balancing the needs of the public and private 
sector (e.g. Gálvez, Nogales and Webber, 2017). To achieve truly inclusive agribusiness, however, it is also important to recognise unequal power relations of other stakeholders and to actively pursue engagement of smallholder farmers, small businesses and women (Fairtrade Foundation, 2014; Oxfam Novib, 2015). Thus, the governance of development initiatives should follow similar principles to democratic governance in public life, empowering citizens to have a say in decision-making processes, improve levels of inclusion of individual citizens in policy processes and increase the legitimacy of decisions made (Michels, 2011). Cotula et al. (2019) call for the development of a sociolegal empowerment framework, whereby smallholders may increase their agency in the realm of commercial agriculture by using a combination of legal processes, improved access to information, greater capacity for collective action and clearer channels for engagement with other actors.

Experience from other public-private partnerships and development projects suggests that achieving meaningful engagement of smallholder farmers and women is a challenge to the status quo. In general, they rarely co-design projects and are inadequately consulted, so awareness is low and structures of engagement are not built in from the start (ASFG, 2013; Fairtrade Foundation, 2014). Often, there is a lack of well-organised, representative farmer groups or apex organisations for project managers to work with. Poole (2017) argues that decision-making and governance are often too centralised, without sufficient input from local or provincial authorities and producer groups who can communicate the complexities and priorities of their specific contexts. Fairtrade Foundation (2014) found that the risk of top-down exclusion is especially high in so-called 'demand-driven' projects - that is, agricultural projects that are driven by the commercial needs of private-sector partners. Another issue is a proliferation of governance bodies such as committees and working groups, especially if their mandates or membership structures change over time. This can lead to farmer groups and civil society becoming marginalised or even leaving the process (see Schut et al., 2014). Women face particular challenges in achieving representation in development projects, owing to competing demands on their time for work and childcare and to the fact that women often have less education and access to decision-making bodies than men (Tanwir and Safdir, 2013).

These experiences suggest that achieving engagement of smallholder farmers, small businesses and women is an ongoing challenge for project managers, yet crucial for the long-term success of the initiative. Given the complexity and power imbalances of spatial development initiatives, engagement will not happen organically; it must be consciously planned for with governance structures and feedback mechanisms, capacity-building and mediation if needed. This is all much easier to achieve if smallholder farmers, small businesses and women are involved from the very beginning of the process, but it is also possible to bring them in and build working relationships and trust over time. 
Eight initiatives - seven development corridors and one growth pole - were selected for study:

\section{Eastern Africa:}

1. Lamu Port-South Sudan-Ethiopia Transport Corridor (LAPSSET) in Kenya

2. Southern Agricultural Growth Corridor of Tanzania (SAGCOT)

3. Nacala Corridor in Mozambique and Malawi, incorporating the ProSAVANA agricultural development programme

4. Beira Agricultural Growth Corridor (BAGC) in Mozambique and Zambia

\section{West Africa:}

5. Lagos-Kano-Jibiya (LAKAJI) Agricultural Growth Corridor in Nigeria

6. Bagré Growth Pole in Burkina Faso

Central and Southern Africa:

7. Lobito Corridor in Angola, linking to Democratic Republic of Congo and Zambia

8. Walvis Bay-Ndola-Lubumbashi Development Corridor (WBNLDC) in Namibia, Zambia and Democratic Republic of Congo

Some of the initiatives were completely agriculturefocused, while others addressed agriculture only indirectly. All were live in 2019, with the possible exception of the LAKAJl Corridor. This corridor development initiative was funded by the United States Agency for International Development (USAID) through the Nigeria Expanded Trade and Transport project, which officially ended in September 2017, and we were not able to ascertain if the Nigerian government or private investors are continuing activities in the corridor region.

This research study was conducted in two stages. In Stage 1 we drew on public documents, academic papers published by researchers who had accessed the inner workings of the initiatives, and eight expert interviews, to assess the participation of small-scale producers (smallholder farmers and pastoralists) and women at different stages of the initiatives' development. The expert interviews were held during the first half of 2018 with researchers and development practitioners who were closely familiar with the initiatives; they are not identified in this paper to protect their anonymity.

Stage 2 involved deeper analysis of five corridor initiatives: BAGC, LAPSSET, Lobito, Nacala and SAGCOT (Figure 2.1). Members of the research team conducted fieldwork in Angola, Kenya, Mozambique and Tanzania. Through interviews and focus groups with farmers, producer organisations, businesspeople, corridor officials, local authorities, NGOs and a range of other stakeholders, we assessed the progress and impacts of each initiative, and expanded the preliminary findings from Stage 1. The fieldwork was conducted during 2018 and 2019, both in rural corridor regions and in cities where corridor and port officials and NGOs are based. 
Figure 2.1. Locations of the five corridors studied in depth

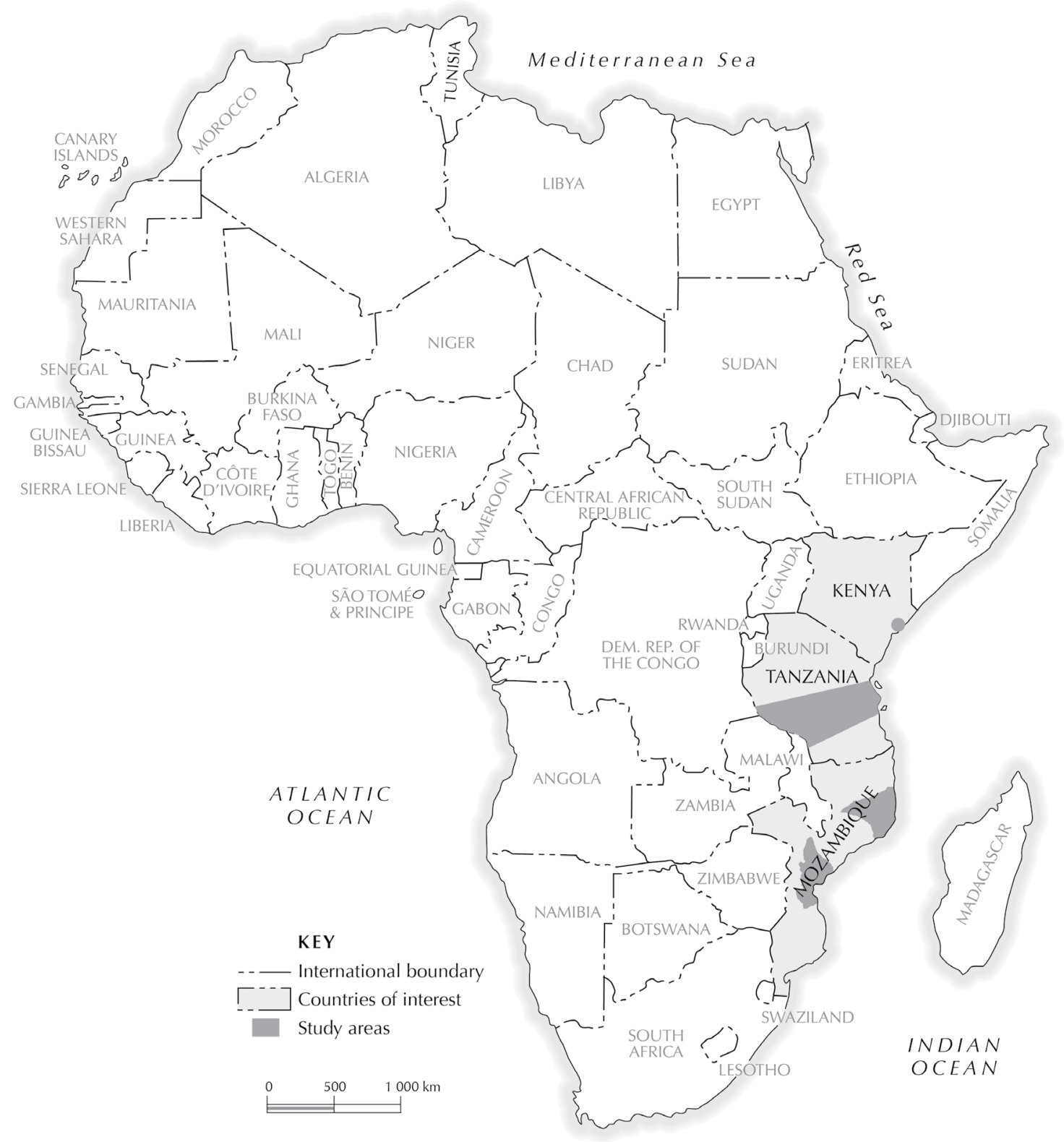

Source: Chome et al. (2020) 


\section{ABOUT THE EIGHT INITIATIVES}

\subsection{Origins}

There has been increased interest and investment in corridors and other spatial development initiatives in sub-Saharan Africa in recent years. For example, the Walvis Bay Corridor Group was established in 2000, proposals for SAGCOT in Tanzania emerged around 2008, and plans for a Nacala development corridor in Mozambique were announced in 2010.

Three major forces have driven this activity (Smalley, 2017). First, private-sector actors such as food manufacturers, mining firms and fertiliser producers have been demanding better road and rail infrastructure, unambiguous access to land, and greater access to rural communities, both to source agricultural commodities from them and to sell agricultural inputs and services to them. African governments are under pressure to support foreign investors in those goals, and corridors and clusters or growth poles provide a neat mechanism to channel investment where it is needed by the private sector. Secondly, governments have been leveraging that investment in infrastructure and business to promote economic development in corridor or cluster regions. In this way, they are continuing a strategy first popularised by New Partnership for Africa's Development in the 1990s with projects such as the Maputo Development Corridor, by transforming historical transport routes into regional development projects. Thirdly, donors and international finance institutions have supported corridors and agricultural clusters or growth poles because these kinds of projects align well with themes that many of those organisations are prioritising, such as infrastructural improvements, cross-border trade, value chain development and linking smallholders to nucleus and/or processor estates ${ }^{4}$ as well as privatesector development.

Detailed reviews of sub-Saharan Africa's corridors and clusters are available elsewhere (see Gálvez Nogales and Webber, 2017; Picard, Coulibaly and Smaller, 2017; Smalley, 2017). These reviews highlight that these initiatives are highly complex projects that emerge from a convergence of interests. Because corridors are so large and complex, they are usually designed as umbrella projects that cover many other types of spatial development initiatives and investments. For example, the Beira Agricultural Growth Corridor is a growth corridor which includes individual privatesector greenfield investments and is linked to the World Bank's PROIRRI irrigation project. Furthermore, the nature of such initiatives tends to evolve over time, with many beginning life as transport corridors using existing or rehabilitated infrastructure, to which development goals are added.

\subsection{Key differences between initiatives}

Three key points of difference were identified between the eight initiatives and similar spatial development initiatives: the degree of local embeddedness; the emphasis in their strategy for agricultural development; and their driving force.

\subsubsection{Degree of local embeddedness}

Some corridor initiatives emphasise the linear movement of goods from the hinterland to the coast, and vice versa. Efforts focus on improving transport infrastructure and soft infrastructure at border crossings and checkpoints. In this way, a corridor can function as a tunnel for channelling raw commodities from inland zones to processors, consumers and ports on the coast. They are not deeply embedded in local economies.

Other corridors were designed to foster more local links, through interventions such as local training programmes, support for small and medium-sized enterprise (SME) business linkages or 'last mile' infrastructure (Smalley, 2017). These development and growth corridors still have a linear corridor aspect but are more networked and mosaic-like than transport, logistics and trade corridors.

At the other end of the scale are clusters and growth poles. They lack the linear emphasis of corridors and are highly locally embedded. Their infrastructure investment is likely to centre on the cluster or growth pole area itself to improve irrigation, last mile infrastructure or warehousing. A disadvantage is that agri-clusters and growth poles may not pay as much attention as other spatial development initiatives to long-distance supply chain linkages. For example, 
farmers in the Bagré Growth Pole in Burkina Faso who received support in irrigated rice production then faced challenges in marketing their rice (interview, expert respondent, 29 May 2018).

\subsubsection{Emphasis in strategy for agricultural development}

Another way in which the eight initiatives vary is in the kinds of agricultural and agribusiness activities and investments they prioritise. Neither LAPSSET nor WBNLDC had set out a clear vision by 2019 for what agricultural development would look like in their corridor regions. They are more accurately understood as trade or economic corridors which have the potential to add an agricultural development component in time. In contrast, the other six initiatives had agricultural strategies, promising an increase in large-scale agriculture, a rise in smallholder productivity and use of inputs, and greater value addition, market linkages and trade. However, the initiatives differ in how much they prioritise each objective. Often, multiple stakeholders who each prioritise different elements may become involved in the same initiative. This can lead to complex project designs and to contradictory project visions.

\subsubsection{Driving force}

A large number of actors are found to be shaping the design and implementation of agricultural spatial development initiatives. Researchers have observed that within and beyond Africa, the strongest influence behind corridor initiatives can vary - typically either the private sector, the host government or a donor or international finance institution will have been the most influential actor (Byiers, Molina and Engel, 2016).
Several of the eight cases were principally driven by the private sector. Fairtrade Foundation (2014) describes such cases as demand-driven initiatives: projects that are shaped by the commercial interests of private-sector partners and focused on commodities of interest to private-sector market actors. In other cases, donors and the host government have been more influential, and a greater proportion of the development cost is met by the state or by grants or concessional loans from donors and development finance institutions. These cases include LAPSSET, which was propelled by the Kenyan government's geopolitical aims, and LAKAJI in Nigeria, which was initiated by USAID. The African Development Bank (AfDB) designed a plan for a new phase of development for the Lobito Corridor, with the support of the Angolan and Zambian governments. The governments of Brazil and Japan have had a strong influence on several initiatives through involvement in project conception and the provision of development finance, particularly in Mozambique and Angola.

A summary of the three key differences between development initiatives is presented in Figure 3.1.

Based on this analysis, and bearing in mind their evolving nature, the eight initiatives can be categorised into four groups:

\section{Transport or early development corridor} which was designed by the state to support extractives and trade but may be beginning to develop a strategy for the agricultural sector. Examples: LAPSSET, WBLNDC

Figure 3.1. Key differences between the eight development initiatives (some cases straddle two categories or evolve from one category to another)

\begin{tabular}{|c|c|c|c|c|c|}
\hline $\begin{array}{l}\text { Degree of local } \\
\text { embeddedness: }\end{array}$ & \multicolumn{2}{|c|}{$\begin{array}{l}\text { Transport, logistics, } \\
\text { trade and early } \\
\text { development } \\
\text { corridors }\end{array}$} & & $\begin{array}{l}\text { Development and } \\
\text { growth corridors }\end{array}$ & $\begin{array}{l}\text { Agri-clusters and } \\
\text { growth poles }\end{array}$ \\
\hline Ground water & \multicolumn{2}{|c|}{$\begin{array}{l}\text { LAPSSET } \\
\text { WBLNDC }\end{array}$} & $\begin{array}{l}\text { Nacala } \\
\text { LAKAJI } \\
\text { Lobito }\end{array}$ & $\begin{array}{l}\text { SAGCOT } \\
\text { Beira }\end{array}$ & Bagré \\
\hline \multirow{2}{*}{$\begin{array}{l}\text { Emphasis in strategy } \\
\text { for agricultural } \\
\text { development: }\end{array}$} & \multicolumn{2}{|c|}{ Not yet articulated } & $\begin{array}{l}\text { Value addition, market } \\
\text { linkages and trade }\end{array}$ & $\begin{array}{l}\text { Productivity and use } \\
\text { of inputs }\end{array}$ & $\begin{array}{l}\text { Large-scale } \\
\text { agriculture }\end{array}$ \\
\hline & \multicolumn{2}{|l|}{$\begin{array}{l}\text { LAPSSET } \\
\text { WBLNDC }\end{array}$} & Lobito LAKAJI & Bagré Nacala & $\begin{array}{l}\text { SAGCOT } \\
\text { Beira }\end{array}$ \\
\hline \multirow[t]{2}{*}{ Driving force: } & \multicolumn{2}{|c|}{ Government } & \multicolumn{2}{|c|}{ Donor or development finance institution } & Private sector \\
\hline & $\begin{array}{l}\text { LAPSSET } \\
\text { WBLNDC }\end{array}$ & $\begin{array}{l}\text { Bagré } \\
\text { Lobito }\end{array}$ & LAKAJI & & $\begin{array}{l}\text { SAGCOT } \\
\text { Nacala } \\
\text { Beira }\end{array}$ \\
\hline
\end{tabular}

Source: Authors' own 
2. Demand-driven agricultural growth corridor, which is driven by the private sector and emphasises large-scale agriculture and some measures on productivity and inputs. Examples: SAGCOT

3. Smallholder-focused corridor or growth pole with a strong emphasis on productivity or value chain development, driven by donors, development financial institutions or government. Examples: LAKAJI, Bagré Growth Pole

4. Hybrid model, evolved from a transport corridor, with both private-sector and government influence and contrasting visions over whether to focus on large- or small-scale agriculture. Examples: Beira, Nacala and its ProSAVANA programme, AfDB plans for expanding on Lobito corridor

These differences do not only affect the character of the initiative. They also affect the likelihood that smallscale producers will be given a voice in the design and decision-making of the initiative, and that they will benefit from the investments.

\subsection{Progress of the eight initiatives in 2019}

\subsubsection{Governance and funding}

As of 2019, each initiative had an established governance structure. This typically included a dedicated office, partnership group or development authority and in some cases a separate administrative secretariat. The governance bodies administered the initiatives and raised and allocated funding. Some, for example, SAGCOT, BAGC and Nacala, established their own catalytic funds to provide concessional loans, grants or private equity finance for corridor projects. The initiatives were typically structured as public-private partnerships, and public and private sources of funding were committed by a wide range of organisations including host governments, bilateral donors such as DFID, USAID and Japan International Cooperation Agency (JICA), lenders such as the World Bank, International Finance Corporation (IFC) and African Development Bank, agri-food and fertiliser companies, and mining, logistics and telecommunications companies. For example, nearly 30 partners pledged around US\$1 billion in investment for SAGCOT (Bergius, 2016). It is doubtful that all these commitments have been realised.

\subsubsection{Corridor infrastructure}

Perhaps the most visible evidence of progress in 2019 was the construction or rehabilitation of hard infrastructure in corridor regions. This included work on the ports of Beira in Mozambique, Lamu in Kenya, Lobito in Angola and Lüderitz in Namibia, and on railways in Angola and Mozambique. Substantial road improvements had taken place, mainly of highways or trunk roads along corridor routes such as the highways in the LAPSSET, Lobito, Nacala, SAGCOT and WBLNDC corridors. There was also some investment in agricultural infrastructure such as irrigation, warehouses and grain stores, abattoirs and processing plants.

However, interviews suggested that much more agricultural infrastructure was needed. Often this meant more investment in rural roads and last-mile transport services. A representative of the BAGC secretariat said: 'We still lack infrastructure, roads, storehouses... the truth is that the EN6 road [a major highway undergoing rehabilitation in central Mozambique] has little impact for smallholders. We need tertiary roads. Seventy per cent of the cost of some products is due to transport costs from the poor road conditions we have' (interview, 22 August 2018). In the Lobito corridor, the lack of good rural roads and access to train stations was compounded by a lack of cargo-loading and storage facilities at the stations and of hauliers willing to serve rural areas.

\subsubsection{Soft trade infrastructure}

Although increasing cross-border trade in Africa is often cited as a potential benefit of development corridor initiatives, there was limited evidence in 2019 for investment in soft infrastructure in this aspect. As part of the USAID-funded Nigeria Expanded Trade and Transport Program, the LAKAJI project included training and technical assistance for customs officials to address bureaucratic and regulatory bottlenecks at Lagos port and along the corridor. The WBLNCD initiative, which is another trade-oriented initiative, eliminated restrictions on heavy motor vehicles and funded activities to reduce HIV/AIDS transmission among truck drivers. Special economic zones had also been established around the cities of Beira and Nacala.

\subsubsection{Large-scale agriculture}

Another area of progress which was highly visible in the agricultural development corridors, especially in Mozambique, is investment in large-scale plantations and farms by domestic and international firms and individuals. In 2012, criticism began building of an apparent boom in large-scale land acquisition, often for soy in the Nacala Corridor region. Associated land disputes and evictions were also reported. In addition, Mozambique's Beira corridor region had several largescale operations for cattle, jatropha and cotton, some of which pre-dated the official launch of BAGC in 
2009. Researchers have found a significant increase in large-scale farms in the Beira region between 2002 and 2012 - more so than in Nacala (Glover, Salvucci and Jones, 2016).

\subsubsection{Agricultural development initiatives}

In Tanzania there was evidence of several activities that could benefit smallholders and small agribusinesses, some of which were catalysed by SAGCOT. This involved a number of schemes to connect or contract small-scale farmers in dairy, rice, sunflower, Irish potatoes, tomatoes and tea. These included USAIDfunded training for rice farmers, support for value addition processing enterprises, and the DFID-funded SAPPHIRE I| project, which involved post-harvest handling and grain storage for smallholder rice and maize farmers.

The BAGC blueprint envisioned a similar range of investments in input provision and post-harvest facilities, but there seemed to have been less investment. Activities included the World Bank-funded PROIRRI irrigation programme and numerous pilot small agribusiness ventures that received funding from the BAGC catalytic fund. As for Nacala, a number of contract farming initiatives funded by JICA and by the Swedish International Development Agency (SIDA) involving smallholders were reported.

\subsection{Positive impacts}

There is some evidence that in 2019 a few smallholders, women and small businesses had benefited from infrastructural improvements and agricultural projects in corridor regions. For example, in Angola, post-war rehabilitation of the Benguela railway was found to have benefited female traders who use the trains to sell their agricultural produce at greater profit. It also triggered a mushrooming of new trading centres and market outlets at train stations and in surrounding areas. By increasing the movement of goods within Angola, the Benguela railway increased the availability of agricultural inputs in rural areas and facilitated a greater flow of information into isolated rural communities thereby benefiting smallholders and women trading food crops and other domestic equipment.

In the LAPSSET region, construction of roads between Isiolo and Moyale in Kenya, and from Moyale to Hawassa in Ethiopia, was reported to have enhanced access to markets, cross-border trade and local investment (LCDA, 2016). During focus group discussions held in the area of Isiolo county, residents of a pastoralist community told researchers that 'construction of the Isiolo-Moyale Road had resulted in many positive developments, with enhanced transportation and market access for their livestock and other produce, increased value for their properties, and other opportunities' (Kibugi, Mwathane and Makathimo, 2016, p. 37). Travel time between Moyale and Nairobi was reduced from about 60 hours (more than three days) to just eight hours.

The PROIRRI irrigation project, which was funded by the World Bank, JICA and the Mozambican government but was designed to align with the BAGC in Mozambique, invested in irrigation equipment and provided funding for increased access to seeds, fertiliser and tractors, which benefited ' 675 horticulture farmers in Sofala and 250 rice farmers' (World Bank, 2016b, p. 7). In Tanzania, a review by DFID noted a range of efforts in training, subsidised inputs, post-harvest or processing support and marketing opportunities. For example, in 2015, 10,461 farmers had attended maize farming training funded by the SAPPHIRE project, and at least four farmer organisations had support to operate grain warehouses (DFID, 2016).

\subsection{Constraints on wider benefits for smallholders and women}

While acknowledging those positive experiences, our research suggests that neither agricultural development corridors nor transport corridors were yet having as beneficial an impact as the planners had projected and as the policymakers and donors had hoped.

The limitations of these corridor developments were due, in part, to considerable challenges of governance and funding. Corridor initiatives have proved difficult to administer and coordinate. The need to balance multiple interests means that the process of moving from concept to implementation is often characterised by delays, disagreements and a reorientation of objectives (Chome et al., 2020). Initiatives can become entwined in local or national politics - for example, in the cases of LAPSSET and SAGCOT, which were destabilised as a result. Resistance from civil society can lead to further delays, as the SAGCOT and Nacala planners experienced. Armed confrontations between political factions in 2013-2016 created further instability in the Nacala corridor; LAPSSET was hindered by the AlShabaab threat and civil war in South Sudan. Realising investment committed by the public and private sectors has also proved challenging. For example, economic pressures led Brazilian agribusiness investors to cool their interest in Mozambican development corridors, while the fall in global oil prices and Uganda's change of its oil routing through Tanzania instead of Kenya undermined plans for LAPSSET.

While the problem with infrastructure may be partly caused by the limited investment available, it may also 
be related to an under-appreciation of the needs and realities of smallholders, small agribusinesses and women, which appears to be limiting the ways in which they can benefit from corridor developments. Our research highlights that whereas joining commercial value chains is championed by corridor proponents as obviously good for smallholders and women, for the farmers and pastoralists themselves it is a much more complex decision. For example, pastoralists and smallholders we interviewed in Lamu, Kenya, expressed concern that opening up the region to commercial agriculture would exacerbate exploitation by local middlemen that they were already facing. Both pastoralists and smallholders are vulnerable, especially pastoralists whose access to pasture and water is becoming increasingly restricted by increased sedentarisation, the spread of communal conservation efforts, and land allocation for LAPSSET activities. In Mozambique, we found that smallholders were hesitant to increase production because they feared challenges in selling their produce. Instead, they preferred to combine agriculture with other livelihoods activities to decrease their vulnerability and spread risks. In the SAGCOT region, pastoralists saw agricultural projects like the large-scale sugarcane estates as encroaching on their grazing areas and blocking livestock routes and water points.

We argue that the needs and realities of smallholders, pastoralists and women could be more fully realised in corridor developments if they had stronger participation and voice in the design, implementation and oversight of the projects, which we explore in the next section. 
In this section we discuss the level of smallholder and women's groups' engagement in each area for the eight cases, to the extent that this was revealed in documents and interviews. Broadly speaking, there are five stages where smallholders and women's groups can potentially engage in development initiatives: 1) Concept and design; 2) Consultation; 3) Land allocation; 4) Governance; and 5) Implementation.

\subsection{Concept and design}

\subsubsection{The blueprint approach}

Corridors and growth poles are very large development and investment initiatives which are conceived and planned by governments, lenders and donors, multinational corporations and consultants. These initiatives are top-down and often externally driven. They rarely involve strategies for supplying local food markets or promoting low-input production systems. Rather, the overriding vision of agricultural and rural development presented in project blueprints is of a modern, high-input, commercialised agricultural sector which is closely linked to global value chains. Very often, the agricultural strategy is to increase production and trade of export commodities. The reasons for prioritising export-led agriculture can include a desire by policymakers to increase foreign exchange, by port authorities to increase port activity, by advisers and policymakers who have identified the high earning potential for farmers of export crops, or by multinational companies to increase or secure raw material supply (Cotula et al., 2014). IFAD advised in 2016, 'Donors and governments ... should look at other markets that may be less beneficial for each individual farmer, but have the potential to uplift many more family farms. The most important strategy for the vast majority of small-scale farmers, yet a strategy that paradoxically receives less international attention, [is] mainstream domestic food markets' (IFAD, 2016, p. 240, emphasis added).

\subsubsection{Challenging a large-scale vision}

With the exception of Lobito Corridor, the architects of agricultural growth corridors and growth poles proposed a mixed sector of large-scale plantations or farms, outgrower or block farm schemes and entrepreneurial medium-sized farms. Policymakers may believe that large-scale agriculture is necessary to drive economic growth and technology transfer. Large-scale investors are also needed to help fund infrastructure. In the case of Bagré Growth Pole, for example, Burkina Faso's government set high requirements of commercial investment for applicants for land to pay for the costs of new irrigation (World Bank, 2011). Large-scale agriculture is especially common in demand-driven initiatives where agribusiness corporations and land investors have a strong influence (Fairtrade Foundation, 2014). These actors often prefer large operations to guarantee production or simply gain access to land as an economic and political asset (Cotula et al., 2014; Cochet, 2017). Medium-sized farmers, meanwhile, may be well represented in plans because policymakers or project implementation staff are medium-scale landowners themselves (interview, expert respondent, 2 January 2018).

There are cases where smaller-scale farming is more prominent in plans. Sometimes the host government requires consultants and investors to plan for smallholder inclusion, such as the government of Tanzania (SAGCOT, 2015; Bergius, 2016); or development partners fund sub-projects that focus on smallholders or women. For example, DFID included three agricultural programmes as part of its contribution to the SAGCOT, of which two (SAPPHIRE and Chai) had a narrow focus on smallholders and targets for reaching female beneficiaries. Overall, we found that spatial development initiatives that are driven by donors or the government are less likely than demanddriven initiatives to support the interests of large-scale agribusiness and more likely to address the interests of small and medium-sized farmers, be it with a focus on productivity, value chains or trade.

After the concept and design stage, unplanned events may reorient the initiative closer towards smallerscale agriculture. One such unintended development occurred with the Bagré Growth Pole, where most agricultural investors involved in the new irrigation scheme had small (less than 30ha) operations focused on food crops. Initially, the government had targeted larger operations, but the high investment costs appear to have led investors to reduce the size of their proposals. This necessary shift was apparently disliked 
by some officials who believed that larger operations would be needed to attract supply chain buyers and thus have a transformational impact (Venot et al., 2017).

\subsubsection{Whose needs?}

An absence of smallholder and small business voices at the concept and design stage means they are unable to challenge incorrect assumptions and the imposition of external priorities for crop production (Fairtrade Foundation, 2014). For example, DFID identified serious flaws in its plans for outgrower schemes in Beira, which were the main strategy for reaching smallholders. DFID noted 'the incorrect assumption that farmers would be willing to work for future revenues even if those are potentially large, as avocado trees take four to six years to fruition' (DFID, 2017, p. 7). Similarly, there has been criticism of the well-intentioned rice and maize schemes of Bagré Growth Pole (Venot et al., 2017). A respondent told us that whereas the heart of the scheme is to promote irrigated rice farming, local farmers wanted the flexibility to grow other crops, such as vegetables (interview, expert respondent, 29 May 2018). In summary, we identified a systematic lack of engagement of smallholders and small-scale businesspeople in the concept and design stage of spatial development initiatives. The resulting development visions are not always appropriate to a smallholder context, but there are ways - both deliberate and unintended - in which the extent of investment in large-scale farms and plantations can be lessened.

\subsection{Consultation}

All eight initiatives included a period of consultation. We use the term 'consultation' in a broad sense, to include baseline and feasibility studies and interactions with potential investors. Consultation provides scope to engage smallholder farmers and herders, smallscale businesses, and residents in corridor or cluster areas. However, although the evidence we reviewed is limited, our findings indicate that these groups were not sufficiently consulted.

\subsubsection{Lost voices}

A common approach was to hold investor roadshows and conferences, whereby government representatives and project proponents hold meetings with investors and logistics, extractives and agribusiness firms to gauge interest and solicit proposals for land-based investment. As an example, the Walvis Bay corridor master plan was validated in May 2014 in a stakeholder workshop after several networking events with investors in Southern Africa and Brazil (WBCG, 2017).
Any agricultural interests involved in consultations were typically multinational or domestic agribusiness companies, as opposed to agricultural cooperatives or other organisations that might represent smallholder or small-business interests. One of the only examples of farmer consultation we found is the inclusion of Zambia National Farmers Union in meetings organised for the Lobito Corridor (Mseteka, 2015). Based on the limited evidence that we reviewed, other initiatives seem to have omitted consultation with famers' groups, unions or cooperatives. For example, Bergius (2016, pp. 7-8) claims that although the Agricultural Council of Tanzania was involved in early discussions on SAGCOT, "the largest network of smallholder farmers in Tanzania Mtandao wa Vikundi vya Wakulima Tanzania (MVIWATA) - has not at any stage participated in deliberations concerning SAGCOT:'

Particularly strong criticism was made of the Nacala consultation process in Mozambique, where it appears that the early ProSAVANA consultations engaged more with farmers from Brazil than with local farmers' organisations (Schlesinger, 2014; see also Clements, 2015, pp. 106-7). The alleged poor quality of initial consultations for ProSAVANA directly led to the formation of the 'No to ProSAVANA!' campaign, which had a big impact on how the project unfolded (Clements, 2015; see below).

A major challenge to effective consultation is a lack of organisations in Africa that can represent both national and sub-national interests of smallholders in consultations. Too often, smallholders are spoken for by metropolitan civil society, overtly political organisations or industry apex bodies or unions that are dominated by the interests of larger producers. In Tanzania, a representative of the national land rights organisation Haki Ardhi called for more engagement of farmers at the grassroots:

I would say, Haki Ardhi or MVIWATA are not suitable organisations to represent smallholders or women. It is the farmers themselves who are supposed to represent their issues about SAGCOT' (interview, 10 May 2018).

There is also a lack of organisations representing the interests of small-scale actors elsewhere in the agrifood supply chain. In Angola, for example, there were concerns that women who use the railway for small-scale food business and are crucial for food trade in the corridor region might not be adequately consulted or otherwise engaged in the Lobito Corridor Trade Facilitation Project because they lack a voice and political representation (interview, expert respondent, 10 May 2018). 


\subsubsection{Impact assessments}

Judging by the literature reviewed, smallholders and women were apparently more likely to have been consulted for feasibility studies and environmental and social impact assessments. Such studies present an opportunity for third parties - including those that were not involved in the concept and vision stage - to highlight potentially negative elements of spatial development initiatives and pose questions. These questions can then be taken up further by farmers' groups and civil society. A strategic environmental assessment conducted for the LAPSSET corridor in Kenya, for instance, found that that the design of LAPSSET was not compatible with the needs and preferences of communities (Repcon Associates, 2017).

The experience from Kenya is instructive. LAPSSET was announced during a time of significant political change in Kenya, with the adoption of a new constitution in 2010 that gave prominence to public participation in policymaking and devolved power to county governments. Kenya already had laws requiring impact assessments (Kibugi, Mwathane and Makathimo, 2016). This has meant that consultation is taken rather seriously for state-backed projects and has fostered an environment for organised activism in corridor regions.

Even if impact assessments are not carried out to a high standard (a charge often levelled at Kenyan assessments; see Kakonge, 2015), the process may provide a rare window for organisations acting on behalf of farmers to engage in the initiative and demand information. A drawback, however, is that impact assessments are typically conducted several months or years after the first consultations and feasibility studies, when visions and objectives have already begun to coalesce.

\subsection{Land allocation}

Some of the eight initiatives involved allocation by the government of land for investment in agriculture and in infrastructure. There has been extensive criticism by domestic and international civil society over this process, which, they allege, infringed the land and access rights of local people and failed to follow proper due diligence, including through participation and consultation of smallholders.

The criticism includes concerns over the process by which village land was made available to investors in the SAGCOT corridor of Tanzania (Bergius 2016); failure of the government's consultations to allow for informal tenure rights of people living in areas earmarked for road constructions in the LAPSSET corridor (Kibugi,
Mwathane and Makathimo, 2016); and claims that farmers were pressured to join ProSAVANA projects and allocate land in Mozambique (Clements, 2015; The Daily Vox, 2017).

In general, a lack of formal tenure security has a negative effect on the ability of women and smallholders to play an influential role in how land is used in the operationalisation of spatial development initiatives (e.g. Kibugi, Mwathane and Makathimo, 2016). If consultations and land-use planning processes are not well managed, there is a risk that the initiative will be co-opted by powerful or well-informed community members with formal tenure and that land management decisions taken at community members will jeopardise the rights of less powerful women and others. On the subject of a SAGCOT 'Land Use Dialogue' process, the representative of Haki Ardhi recalled: 'The participation is very poor. I asked, we are going to a meeting of over 40 scholars, activists, et cetera... then you only bring one man and woman from Iringa a day before who must be assisted by SAGCOT in translation? So, this is not good at all' (interview, 10 May 2018).

The Bagré Growth Pole Project in Burkina Faso provides a more positive example of consultation with smallholders over land allocation. Because this project involved relocating villagers, and because of concerns over land rights grievances relating to an earlier project (Venot et al., 2017), the project administrator Bagrépôle conducted extensive land-use mapping with communities (CGIAR, 2016, p. 3). In 2012, the government published a decree that a comprehensive land survey must be conducted before irrigation infrastructure construction starts and that affected people have priority over subsequent land allocation (Venot et al., 2017). Nevertheless, it should be noted that the government had designated much of the local area as a Zone d'Utilité Publique, which gave it the right to expropriate people for the sake of public interest (Grow Africa, 2014). Furthermore, the land allocation arrangements that were designed by the World Bank and Bagrépôle as a result of the land-use mapping have been criticised for being based on unrealistic assumptions of the yields that farmers could expect to attain (CGIAR, 2016; Venot et al., 2017).

\subsection{Governance}

Our review suggests that smallholders are rarely given a position at the centre of governance or decision-making of agricultural investment initiatives. We were not able to view the membership details for each case, but the information we could access suggests that smallholders and women were not usually represented in governance bodies such as fund managers, secretariats, committees, councils or 
boards. Although the agricultural sector may have a seat at the table, its representatives tend to be from agribusiness companies rather than farmers' groups or cooperatives. In the case of LAPSSET, which is a less agriculturally oriented initiative than the other initiatives, it appeared that there was no one of the Board of Directors who had obvious experience in working with farmers, and it was reported that in at least one area of the corridor, Isiolo, the government was conducting community information-sharing and negotiations through the local county council (Sena, 2012, p. 17).

More positive examples include the Board of the BAGC Partnership, whose rules stipulated that its five directors must include a representative of a national farmers' organisation. In Burkina Faso, smallholders had no decision-making in the Bagré Growth Pole governance structure, but the Bagrépôle administrators provided training for local participants to organise into farmers' groups and women's groups (interview, expert respondent, 29 May 2018).

One aspect of governance which could improve responsiveness to the needs of smallholders and women is systems for monitoring and accountability. In addition to the question of smallholder representation and accountability of their own actions, governance bodies also need to be strong enough to call investors and national governments to account over their commitments to smallholder inclusion (Jenkins, 2012; DFID, 2016). When the initiatives included programmes funded by the World Bank, IFC or AfDB, there were likely to be policies which call for smallholder interests and women's rights to be protected (e.g. World Bank, 2016a). Furthermore, the presence of foreign national governments as development partners may help to increase accountability in spatial development initiatives. Indeed, the fact that ProSAVANA was explicitly a triangular cooperation programme, with Brazil and Japan taking high-profile roles alongside Mozambique as ultimate architects and sponsors of the programme, seems to mean that the Brazilian and Japanese governments were more visible and more accountable than foreign governments in other cases (Monjane, 2017).

\subsection{IImplementation}

Once corridor and growth pole initiatives have been established, the process of implementing the plans is slow and complex. There are three main considerations that affect inclusion during the implementation phase: whether smallholders and women's groups are engaged in ongoing consultation and awarenessraising, whether they can access funding and whether they participate in activities and business ventures.

\subsubsection{Ongoing input, consultation and awareness- raising}

According to the theories of effective participation referred to earlier, consultation of smallholders and women's groups should continue into the implementation phase of agricultural investment projects. Although external lenders and donors may have pushed for inclusivity, they are not necessarily the best-placed institutions for responding to changing priorities or emerging grievances. Smallholders and women need to be represented in the decisionmaking and governance bodies of spatial development initiatives to have an input into how activities linked to the infrastructure components of corridors and growth poles are put into practice. In the Beira corridor, for example, there was criticism that local farmers were excluded from decision-making in a project involving seeds (Joala, 2016).

Some initiatives took steps to increase awareness, if not decision-making, among farming communities. In Burkina Faso, a radio station called Bagrepole FM was launched to cover $100 \mathrm{~km}$ of the development zone, which may have helped to inform local farms if not give them a voice (interview, expert respondent, 29 May 2018). In Nacala, a communications strategy aimed at nullifying civil society opposition included a radio campaign, distribution of flyers in local language and staging plays (ProSAVANA, 2018; No! to Landgrab Japan, 2016b).

Yet the logistical constraints of conducting awarenessraising campaigns in large crop farming and pastoralist regions are surely likely to have limited the impact of such campaigns, aside from any questions of deliberate lack of transparency on the part of project implementers. For example, in Kenya, the authors of the LAPSSET Strategic Environmental Assessment noted low literacy levels in many communities and reported that 'without exception all stakeholders... complained of lacking information about LAPSSET' (Repcon Associates, 2017, p. xxiii). However, it should be mentioned that efforts could have been made to find alternative ways of communicating with communities, for example through radio, social media, dance and dramatisations such as the examples mentioned in Burkino Faso and Nacala.

It is harder for initiatives that were initially focused on extractives or logistics, such as LAPSSET, Lobito, Nacala and WBLNDC, to incorporate farmer programmes and measures at a later stage. Embedding agribusiness priorities, especially of smallscale farmers, pastoralists and businesspeople, into blueprints, governance structures and planning seems to be quite a slow process if these individuals were 
not already being engaged with and thought about in the concept and design and consultation stages. In Angola, for instance, the AfDB mooted a trade facilitation programme that targets small-scale value chains, but the raison d'être of the Lobito rail corridor has always been to transport goods between copper mines and the coast. The main barriers to greater involvement of smallholders and women traders have been a lack of information among officials and the focus on copper transportation.

\subsubsection{Access to funding}

Using project documents, we investigated whether smallholders were able to participate in spatial development initiatives by accessing finance. Aside from credit that may be offered to smallholders through outgrower schemes, we found three examples of farmer-focused finance being offered: Farmcrowdy, a digital platform for sponsoring smallholders of 1-2ha in Nigeria, which appeared to be informally linked with the LAKAJI project; support for National Microfinance Bank of Tanzania to provide loans in the SAGCOT region; and a programme of matching grants and cash transfers for activities launched within the Bagré Growth Pole Project. Such examples are rare. We believe that this is because corridors and growth poles are based on the theory that improving the local investment and business environment will stimulate agricultural commercialisation and modernisation. This theory precludes the inclusion of micro-financing for individual farmers in corridor and growth pole designs. Hence, when the World Bank became a funder of a substantial SAGCOT project in 2016, it justified its strategy of funding agribusinesses by stating that if the Bank just gave the funding to smallholders directly, SAGCOT would risk being 'largely production-driven and insufficiently market-driven' (World Bank, 2016a, p. 14).

In accordance with this theory, most of the initiatives include provision of higher-value funding to local businesses in the agriculture sector through matching grants. The grants are not intended to serve as microloans for farmers, but rather as business loans for local SMEs and agribusinesses who are expected to increase up- or down-stream activity and thereby contribute to local economic development. For example, Beira's Smallholder Support Facility for outgrower schemes or projects to address constraints faced by smallholders in accessing support services offered up to US\$100,000 and required applicants to submit written proposals to the BAGC secretariat, while the smallest value available from the Beira Catalytic Fund is $£ 40,000$. While farmer cooperatives may be able to access such grants if large enough (e.g. the Nacala corridor farmers' group Forúm IAPACA accessed a MZN 250,000 loan from ProSAVANA), generally, most of the funding seems to have been awarded to input companies and agribusiness aggregators and processors.

Although smallholders are unlikely to avail of such matching grants directly, most of these funding schemes did stipulate smallholder inclusion as one of the eligibility criteria. An example is the Africa Fertiliser and Agribusiness Partnership's matching grants scheme for input dealers in Beira, which required the dealers to arrange field days and demonstration plots for farmers - albeit with the purpose of stimulating demand for fertiliser among smallholders (African Fertilizer and Agribusiness Partnership, 2017). According to one document, JICA added conditions to the rules of a new Nacala Fund in 2012, such that the fund must 'consider the concerns of small-scale farmers and contribute to poverty alleviation' and must follow the international Principles for Responsible Agricultural Investment (No! to Landgrab Japan, 2016). The LAKAJI initiative in Nigeria offered grants to local entrepreneurs, who were encouraged to connect their proposals to SMEs and small producers and engage with women and youth (Nigeria NEXTT, 2017).

Matching grants and other funding sources were typically managed by a fund manager. Their ability to reach smallholders and women was affected by their organisational capacity, the closeness of their links to other actors and the consistency of their ultimate objective. In the case of SAGCOT, West and Haug (2017, p. 423) described a lack of coordination between national oversight bodies and local activities driven by donors and investors, partly because the fund set up to finance local agribusiness activities was not institutionally anchored in any national governance frameworks. In Mozambique, DFID explained that '[fund manager] AgDevCo's need to ensure its own commercial sustainability means that it increasingly invests in bigger, commercial agri-businesses to diversify its portfolio and reduce its risk exposure' (DFID, 2017, p. 7).

\subsubsection{Access to activities and business ventures}

We can also consider access by smallholders and women to activities provided as part of corridors and growth poles, such as training, participation in outgrower schemes and access to inputs. The literature suggests that smallholders were involved in multiple activities and business ventures funded by donors or private-sector partners of corridors and growth poles. In some cases the activities and business ventures were clearly initiated by the corridor or growth pole organisers; in others, it appears that they would have taken place anyway. 
The activities and ventures are wide-ranging, and include: ${ }^{5}$ rehabilitating or introducing irrigation for smallscale farming (Beira, Bagré); expanding outgrower schemes or brokering new contracts between smallholders and traders and processors (SAGCOT, Beira, Nacala/ProSAVANA, LAPSSET, Bagré); training, extension and capacity-building for smallholders to take advantage of opportunities emerging from the new infrastructure and value chains (SAGCOT, Beira, ProSAVANA, LAPSSET, Bagré); establishment of storage facilities and packhouses (SAGCOT, Bagré); and improving farmers' access to seeds, fertiliser, machinery and other inputs (SAGCOT, Beira, LAPSSET, Bagré). In many cases, it appears that smallholders were engaged through cooperatives or associations, rather than on an individual basis.

This appears promising, but we need more information to assess whether certain farmers and pastoralists were excluded because they were too small or lacked sufficient capital and assets. In Beira, smallholdings under 5ha were not included in the corridor blueprint and 5 ha minimum was required for participation in serviced farm blocks. A review by DFID of SAGCOT impacts found that 'Typically the poorest farmers do not get priority treatment whereas the better off receive a large share of the benefits. This is principally for two reasons: the entrepreneurial few tend to rise to the top; and the drive by project implementing partners to identify "early bird" benefits and engage with "low hanging fruit"' (DFID, 2016, p. 5).

More information is also needed to assess whether the smallholder-oriented activities and business ventures have achieved proportional participation of female farmers and business owners. Some of the documents we reviewed do address women's inclusion. For example, AfDB specified that women's cooperatives would be included in its Lobito Corridor programme (AfDB, 2017a); in Burkina Faso, the World Bank set (relatively low) targets for including women among Bagré programme beneficiaries (Bagrépôle, 2014); and DFID has reported on the percentage of women reached through its Beira interventions (DFID, 2017). However, this aspect needs further investigation. 


\section{CROSS-CUTTING FINDINGS AND EMERGING SUCCESS STORIES}

\subsection{Challenges to engagement}

The preceding section argued that the engagement of smallholders and women's groups has been mostly sub-optimal in all stages of the eight corridor and growth pole initiatives, from conception and design to project implementation. Our review suggests that the chances of smallholder and women's group inclusion are highest in spatial development initiatives that: are demand-driven and/or strongly influenced by donors or development institutions that prioritise smallholder infrastructure or value chain programmes (as opposed to large-scale agriculture and nucleusoutgrower schemes); and are not strongly influenced by agribusiness firms whose strategic priorities include large-scale land acquisition or commodity extraction.

If we return to our typology from Section 3.2, this suggests that the most promising type of initiative from the point of view of smallholders and women's groups is the 'smallholder-focused corridor or growth pole with a strong emphasis on productivity or value chain development, driven by donors, development financial institutions or government' - such as the LAKAJI and Bagré Growth Pole.

There are challenges for governments, donors and lenders or the managers of corridors and growth poles to ensure effective engagement of smallholders and women's groups in spatial development initiatives. These challenges include:

- The need to balance interests of multiple parties in public - private partnerships.

- The need to attract investment and facilitate land acquisition.

- A lack of effective representative bodies for smallholders and businesses in many countries, especially at the local and sub-national government level.

- Antagonistic civil society organisations which in some cases campaign against the commercialisation of small - scale farming.

- Unhelpful project designs from external parties based on incorrect assumptions and a lack of understanding of local context.
- Inadequate information and communication channels between and among stakeholders and decision-makers.

- Logistical challenges in reaching residents and resource users in rural areas.

\subsection{Factors that enable success}

Despite the challenges, the literature and interviews provide us with examples of where the needs of smallholders and women were being taken more seriously in spatial development initiatives. We identify three main reasons for this:

1. Enabling policies of governments and development partners;

2. Project proponents learning from the lessons of past initiatives;

3. Mediation and innovation from third parties.

These are discussed below, but we would first like to make a brief observation that in cases where an initiative took steps to ensure or increase smallholder participation, it sometimes led to delays. This included the household mapping in Bagré, the negotiations of a new Master Plan draft in Nacala, or caution over SAGCOT implementation in the face of civil society opposition in Tanzania (Club of Mozambique, 2017; West and Haug, 2017; Venot et al., 2017). This needs to be acknowledged and addressed in any recommendations for spatial development initiatives to ensure smallholder inclusion and women's development in future.

\subsubsection{Enabling policies of governments, donors and lenders}

Certain policies of governments, donors and lenders appeared to improve the conditions for smallholders and women to be involved in initiatives. These included Kenya's law on impact assessments; or the LAKAJI project's measures to increase youth participation in agriculture, which appear to come from strategic priorities of the Nigerian government and its development partner (USAID). Further enabling policies are listed in Table 5.1. Although these policies are important, it should be noted that their effect can 
be limited and they can be relatively easily overridden by corporate or political interests.

The strategic influence of governments, donors and lenders helps to ensure that the interests of smallholders are represented in initiatives - at least on paper. For example, Bagré Growth Pole seems to have been designed by the World Bank and the government with little private-sector influence. Both in documents and in terms of implementation, Bagré Growth Pole has markedly more clarity of purpose and greater focus on smallholders and small business than initiatives which were heavily influenced by the private sector.
Although like Bagré Growth Pole the LAKAJI plan had some commercial private-sector elements, because it was fundamentally a trade and value chain programme with no substantial private-sector backers or anchor businesses, the emphasis was on hard and soft infrastructural improvements to benefit small and medium-scale farmers. The LAKAJI investment blueprint architects were clearly thinking about how to improve marketing conditions for smallholders, took note of existing programmes of government or donors that targeted small farmers, and seem to have given some consideration of food security. Nevertheless, we do not have any evidence that the architects consulted

Table 5.1. Policies that enable engagement of smallholders and women's groups

\begin{tabular}{|c|c|}
\hline Stage & Enabling policy \\
\hline Concept and design & $\begin{array}{l}\text { - Government policy requires agricultural investments to include } \\
\text { smallholders and set limits on the size of large-scale operations. } \\
\text { - Government encourages planners to seek downstream partners } \\
\text { and investors, which will help to guarantee buyers for produce and } \\
\text { to support local or regional business opportunities in value addition, } \\
\text { processing and marketing. } \\
\text { - Donor policy for programmes and interventions includes smallholder } \\
\text { inclusion or women's empowerment. } \\
\text { Planners create forums or spaces for stakeholders to hold a dialogue } \\
\text { on potential risks and benefits and agree priorities for infrastructural } \\
\text { investment. }\end{array}$ \\
\hline Consultation & $\begin{array}{l}\text { - Government or donor policy requires an impact assessment to be } \\
\text { undertaken, especially if it stipulates public participation. } \\
\text { - Political devolution encourages participation of stakeholders at local } \\
\text { level. } \\
\text { Donors and development partners fund capacity-building to ensure } \\
\text { that farmers' groups, women's groups or other stakeholder interests } \\
\text { have sufficient capacity for organisation and professional participation. }\end{array}$ \\
\hline Land allocation & $\begin{array}{l}\text { - Government policy requires land surveying prior to development. } \\
\text { - } \quad \text { Government policy prioritises land titling or other measures to ensure } \\
\text { land tenure secure security prior to investments. } \\
\text { - } \quad \text { Local-level land management institutions are democratic. }\end{array}$ \\
\hline Governance & $\begin{array}{l}\text { - Policies of development partners and investors include due diligence, } \\
\text { safeguards, monitoring and accountability measures. } \\
\text { Initiative sets quotas for minimum representation of small-scale } \\
\text { producers, including women, on management committees or similar } \\
\text { governance structures. }\end{array}$ \\
\hline Implementation & $\begin{array}{l}\text { - Smallholder inclusion is included as a selection criterion in government } \\
\text { or donor policy for matching grants or similar funds. } \\
\text { Policies of development partners, investors and fund managers } \\
\text { include micro-finance, patient capital and long-term funding } \\
\text { commitments. }\end{array}$ \\
\hline
\end{tabular}

Source: Authors' own 
smallholders, or that they considered inclusion or gender in the agribusiness models that they proposed.

\subsubsection{Measures for more participatory governance}

The literature provides examples measures to improve the engagement of smallholders in the governance of public-private partnerships and other development projects. Some projects set quotas to ensure a minimum representation of farmers, or women, on management committees or similar governance structures (Saint Vil, 2011). Simultaneously, project partners can ensure that farmers' groups, women's groups or other stakeholder interests have sufficient capacity for organisation and professional participation (Mansuri and Rao, 2013; Fairtrade Foundation, 2014). Mechanisms for information-sharing and transparency may be designed (Vogelsperger, Lakoussan and Teshome, 2017). Project managers can experiment with additional forums, outside formal governance structures, for creating two-way communication channels with smallholders, women's groups and small business. The agribusiness incubator 2SCALE reports the example of a dairy value chain project in Nigeria, where the partners decided to hold pre-meetings with farming communities before official partnership meetings:

'All core partners spend one full day in the field, with farmers and other stakeholders (vet service providers, transporters, feed suppliers, community livestock workers, etc.) to interact with them and get their inputs on the Program's progress. In 2016, this went a step further, with the organization of separate meetings with Fulani men on the one hand and Fulani women on the other hand, to give women more opportunities to speak up' (Vogelsperger, Lakoussan and Teshome, 2017, p. 7).

Similar examples were visible among the eight corridors and growth poles in this study. Note, for example, the land-use mapping conducted by Bagrépôle and its organisational training for local farmers' and women's groups; and the rules for representation on the governance bodies of BAFC and SAGCOT. Where the policies of a corridor or growth pole include extensive and effective awareness-raising and consultation, and minimum inclusion of smallholder and women representatives in their decision-making bodies, they move closer to the ideals of empowering, transformative participation.

We also saw some limited positive examples of activities during the implementation stage of a corridor or cluster initiative that engaged with and supported smallscale actors. All of the initiatives for which documents were available (Bagrépôle, Beira, LAPSSET, Nacala/ ProSAVANA and SAGCOT) reported activities that supported small-scale livelihoods through infrastructure, training, improving access to inputs or facilitating market linkages.

\subsubsection{Constructive resistance}

Resistance to plans for corridors or growth poles is very common. Opposition has been widely documented for SAGCOT, Beira, Nacala/ProSAVANA, LAPSSET and Bagré. Although it has not always led to change, we believe that resistance from farmers' groups and civil society can result in greater smallholder involvement.

It has been argued that smallholders lack representation in Tanzania and Kenya (DFID, 2016; 15; Sena, 2012). Yet opposition to SAGCOT and LAPSSET has still been articulated strongly, mainly because the campaigning against corridor development was taken up by activists, local NGOs as well as national and international NGOs that advocate for land rights and pro-smallholder policies, and by environmental NGOs. Kenya saw long-lasting resistance to LAPSSET infrastructural developments in Lamu County by the Save Lamu coalition. In Tanzania, civil society opposition led the SAGCOT Centre to introduce a Memorandum of Understanding with some key farmers' groups that represented thousands of smallholders (West and Haug, 2017, p. 427). Later, international actors led by the International Union for the Conservation of Nature (IUCN) helped to set up a Green Reference Group in 2016, through which implementers of SAGCOT began to engage with non-state actors, including farmers, and the Land Use Dialogue - 'an inclusive multi-stakeholder platform for debate on proper planning and use of land in the SAGCOT region' (SAGCOT Centre, 2016, p. 8).

In other countries, smallholder groups have had a stronger voice. This includes Burkina Faso and Mozambique. Here, a network of local and international groups formed effective coalitions of resistance, linking local smallholders' concerns to broader advocacy around food sovereignty and land rights. Burkina Faso is the host of the West African farmers' organisation ROPPA (Reseau des Organisations Paysannes et des Producteurs Agricoles de l'Afrique de l'Ouest), which has been involved in high-profile criticism of land grabbing in Africa in recent years. In 2015, the national smallholder organisation, Confederation Paysanne du Faso, joined forces with ROPPA to object to the plans for Bagré Growth Pole, and began to organise a series of workshops with local and French NGOs, activists and a prominent farmers' union from Bagré, UGPRB (Confederation Paysanne du Faso, 2016). 
In Mozambique, there was strong and effective resistance to the ProSAVANA project by the national peasants' union UNAC (União Nacional de Camponeses) and ADECRU (Acção Académica para o Desenvolvimento das Comunidades Rurais), comprehensively documented by Clements (2015). As in Burkina, the national organisations made connections with international NGOs. JICA, under pressure from Japanese NGOs, drove changes to the ProSAVANA Master Plan in order to reduce the emphasis on large-scale agribusiness and increase the emphasis on smallholder farming. On paper, the result was greater inclusion of smallholders at the implementation stage. However, some researchers claim that in practice, the interests of large-scale investors and the commercial soy lobby remained dominant in Nacala (No! to Landgrab Japan, 2016; Shankland and Gonçalves, 2016). Furthermore, the resistance became splintered and polarised (Club of Mozambique, 2017; Farmlandgrab, 2017).

In Mozambique and elsewhere, it is through the work of donor-funded NGOs that smallholders and women build their capacity for negotiation and advocacy, strengthening their capacity to engage with government and investors. Often the vehicle for farmers and women to access NGO support is through producer associations, which facilitate access not only to agricultural inputs but also to information, government officials and capacity-building programmes.

\subsubsection{Mediation and innovation from third parties}

While specialised NGOs are best placed to work on advocacy with local communities and to support them in their goals, a common pattern is for them to coalesce into coalitions over time and link up with international NGOs to amplify their message and tap funding. This links to another factor which can increase the articulation of smallholder and women's needs in spatial development initiatives: the role of third parties as mediators and enablers of innovative solutions.

The best example of this was observed with the Bagré Growth Pole project. Here, it appears that the French research institution CIRAD played an important role as intermediary between local farmers and the administrators of the project, Bagrepole, and the World Bank. Engaged as an official partner to the project, CIRAD conducted action research and analysis which revealed farmer preferences over crops and challenged assumptions made by project planners about yields and land allocation (CGIAR, 2016). CIRAD was able to articulate these findings to the administrators and advocate for greater participation of smallholders.
In Tanzania, the land rights organisation Haki Ardhi trained 700 voluntary Land Rights Monitors in communities throughout the country, including in the SAGCOT corridor region. A staff member explained: 'These people help us explain to their fellow villagers what the implications of SAGCOT in the long run are and what the practices in other countries in contract farming are, et cetera' (interview, 10 May 2018).

Lessons from Mozambique tell us that mediators must take care to avoid establishing institutions that risk being seen either by civil society as mechanisms used by corridor proponents to counter resistance or by project managers as overly political groups that lie too far from the mainstream dialogue. Mediation by a development partner can also be resource-intensive (Oxfam Novib, 2015). Bearing these caveats in mind, we can conclude that there are likely benefits when spatial development initiatives are open to full engagement of third parties who can act as mediators or introduce innovative practices and technologies that increase participation and dialogue. 


\section{CONCLUSION}

According to the documentary review, fieldwork and expert interviews involved in this research, smallholder and women's organisations were only minimally involved in the governance of African corridor and growth pole projects as of 2019. This was partly because smallholders and women's groups were rarely, if ever, invited to contribute to the initial conception and design of the initiatives. As the projects unfolded, land rights abuses occurred, and some poorly designed support programmes were initiated. However, there were some attempts at engagement of smallholders during phases of consultation, land allocation and project implementation.

Challenges to increasing and deepening their engagement included: a lack of effective organisations to represent small-scale farmers and businesses; inadequate structures for information-sharing, monitoring and accountability; some incorrect assumptions and biases; overly centralised planning and decision-making; and the need for project planners to address the sometimes contradictory infrastructure and commercial needs of private-sector investors.

The findings in this study suggest that the prospects of smallholder and women's group inclusion may be better in corridors and growth poles that on the one hand, are strongly influenced by donors or development institutions that prioritise smallholder infrastructure or value chain programmes; and on the other are not strongly influenced by agribusiness firms whose strategic priorities include large-scale land acquisition or commodity extraction.

There are measures that project managers, governments, donors and lenders can take to improve the engagement of smallholders, women's groups and small agribusinesses, and therefore increase the likelihood of achieving long-term sustainability of projects and broad development outcomes. For example, they can build the capacity of farmers' and women's organisations to participate in decision-making structures and set quotas for their inclusion in governance bodies. Governments and lenders can introduce requirements for smallholder inclusion and gender-sensitive approaches as conditions and selection criteria for agricultural investments, farmer training and value chain programmes, while project managers can establish communications and monitoring procedures.

Overall, the managers of corridor and growth pole projects must learn from the lessons of past initiatives and begin dialogues with small-scale agricultural actors in corridor regions as soon as possible in the development process to build trust, incorporate their needs into the design and develop structures for sustained engagement over time.

Outside official project management and policy channels, smallholders and women can also increase their engagement through activism and lobbying. They may even be effective in changing project blueprints. These energies can be amplified and channelled by neutral third parties who can help to mediate between stakeholders and develop innovative ways in which the voices of smallholders and women can be heard. 
African Centre for Biodiversity. (2015) Agricultural Investment Activities in The Beira Corridor, Mozambique: Threats and Opportunities for Small-Scale Farmers, Johannesburg: African Centre for Biodiversity. Available at:https:// www.researchgate.net/publication/283299823_Agricultural_investment_activities_in_the_Beira_Corridor_ Mozambique_Threats_and_opportunities_for_small-scale_farmers_ACB_report (Accessed: February 2018)

African Development Bank (AfDB). (2017a) Lobito Corridor Trade Facilitation Project, Abidjan: African Development Bank

African Development Bank (AfDB). (2017b) Multinational (Zambia, with Benefits Spilling to other Corridor States: ANGOLA and DRC). Lobito Corridor Trade Facilitation Project, Abdijan: RDGS Department, African Development Bank.

African Fertilizer and Agribusiness Partnership. (2017) Mozambique [Online]. Available at: https://www.afappartnership.org/volunteer-programme/success-stories/mozambique/ (Accessed: February 2018)

African Smallholder Farmers Group (ASFG). (2013) Supporting Smallholder Farmers in Africa: A Framework for an Enabling Environment [Online]. Available at: www.asfg.org.uk/framework-report/overview (Accessed: February 2018)

Bagrépôle (2014) Etat de mise en Oeuvre du Projet Pole de Croissance de Bagre [Online]. Available at: https:// www.me.bf/fr/file/67/download?token=y8FQn917 (Accessed: February 2018)

Bergius, M. (2016) 'Expanding The Corporate Food Regime In Africa Through Agricultural Growth Corridors: The Case Of Tanzania', Draft paper presented to Colloquium on Global Governance/Politics, Climate Justice and Agrarian/Social Justice: Linkages and Challenges, The Hague, 4-5 February 2016.

Byiers, B., Molina, P.B. and Engel, P. (2016) Agricultural Growth Corridors: Mapping Potential Research Gaps on Impact, Implementation and Institutions, ISPC Study on Agricultural Growth Corridors, Rome: CGIAR. Available at:https://ispc.cgiar.org/sites/default/files/ISPC_StrategyTrends_DevelopmentCorridors.pdf(Accessed: February 2018)

CGIAR. (2016) Managing Water Infrastructure and Equitable Land Compensation Schemes in Irrigation Projects For Social And Environmental Benefits: Results From The 'Managing Bagré For Equity And The Environment Project Led By CIRAD. WLE Briefing Series no. 8. Rome: CGIAR. Available at: https://cgspace.cgiar.org/bitstream/ handle/10568/79392/WLE\%20Brief\%20-\%20Improving\%20Livestock\%2OFodder\%20Production\%20-\%20 WEB.pdf?sequence=1 (Accessed: February 2018)

Chamberlain, W. and Anseeuw, W. (2019) 'Inclusive Business in Agriculture: Defining the Concept and its Complex and Evolving Partnership Structures in the Field', Land Use Policy, 83, p. 308-322.

Chome, N., Gonçalves, E., Scoones, I. and Sulle, E. (2020) 'Demonstration Fields', Anticipation, and Contestation: Agrarian Change and the Political Economy of Development Corridors in Eastern Africa', Journal of Eastern African Studies 14(2), p.291-309.

Christiaensen, L. and Demery, L. (2017) 'Myths Become Realities - or do They?' in Christiaensen, L. and Demery, L. (eds.) Agriculture in Africa: Telling Myths from Facts. Washington, D.C.: World Bank Group

Clements, E.A. (2015) Brazilian Policies and Strategies For Rural Territorial Development In Mozambique: SouthSouth Cooperation And The Case Of Prosavana And PAA. MA Thesis, Sao Paulo State University: Sao Paulo. Available at: http://www2.fct.unesp.br/nera/Itd/dissertacao_liz_2015.pdf (Accessed: February 2018) 
Club of Mozambique. (2017) 'Civil Society Organizations from Mozambique, Brazil and Japan Reiterate Opposition to ProSavana', Club of Mozambique, 27 October. Available at: https://clubofmozambique.com/news/civil-societyorganizations-from-mozambique-brazil-and-japan-reiterate-opposition-to-prosavana/ (Accessed: February 2018)

Cochet, H. (2017) 'Capital-Labour Separation and Unequal Value-Added Distribution: Respositioning Land Grabbing in the General Movement of Contemporary Agricultural Transformations', Journal of Peasant Studies, 45(7)

Confederation Paysanne du Faso. (2016) 'Rapport Atelier Regional'. Paris: Inter-Reseraux Developpement Rural. Available at: https://www.inter-reseaux.org/wp-content/uploads/inter-reseaux_rapport_annuel_2016.pdf (Accessed: February 2018)

Cotula, L. et al. (2014) 'Testing Claims about Large Land Deals in Africa: Findings from a Multi-Country Study', Journal of Development Studies, 50(7), p. 903-925.

Cotula, L., Polack, E., Berger, T. and Schwartz, B. (2019) Actors of Change: Can Socio-Legal Empowerment Support Rural Producer Agency?, IIED Briefing, London: IIED. Available at: https://pubs.iied.org/17499iied (Accessed: February 2018)

DFID. (2016) Annual Review: Southern Agricultural Growth Corridor Programme [Online]. Available at: https:// devtracker.dfid.gov.uk/projects/GB-1-202844/documents (Assessed: February 2018)

DFID. (2017) Project Completion Review: Beira Agricultural Growth Corridor (BAGC) Catalytic Fund [Online]. Available at: iati.dfid.gov.uk/iati_documents/5766506.odt (Accessed: February 2018)

ERM. (2013) Southern Agricultural Growth Corridor of Tanzania (SAGCOT) Investment Project: Strategic Regional Environmental and Social Assessment, SRESA Report, Tanzania: ERM.

Fairtrade Foundation. (2014) A Seat at the Table? Ensuring Smallholder Farmers are Heard in Public-Private Partnerships, A Fairtrade Foundation Executive Summary, London: Fairtrade Foundation.

Farmlandgrab. (2017) 'No to ProSAVANA campaign considers the redesign and public consultation process of ProSAVANA's Master Plan to be fraudulent [Online]'. Available at: https://www.farmlandgrab.org/post/view/26688no-to-prosavana-campaign-considers-the-redesign-and-public-consultation-process-of-prosavanas-masterplan-to-be-fraudulent (Accessed: February 2018)

Gálvez Nogales, E. (2014) Making Economic Corridors Work for the Agricultural Sector. Agribusiness and Food Industries Series 4, Rome: FAO.

Gálvez Nogales, E. and Webber, M. (eds.) (2017) Territorial Tools for Agro-Industry Development: A Sourcebook, Rome: FAO.

Global Water Initiative. (2015) Plan d'Action pour l'Amelioration des Services du Conseil Agricole Dans la Plaine Amenagee de Bagre au Burkina Faso [Online]. Available at: https://pubs.iied.org/sites/default/files/pdfs/migrate/ G04207.pdf (Accessed: February 2018)

GROW Africa. (2014) Agricultural Partnerships Take Root Across Africa: 2nd Annual Report on Private-Sector Investment in Support of Country-led Transformations in African Agriculture, 2013-2014. Available at: https:// www.weforum.org/reports/grow-africa-report-2014 (Accessed: February 2018)

Hickey, S. and Mohan, G. (2004) 'Towards Participation as Transformation: Critical Themes and Challenges', in Hickey, S. and Mohan, G. (eds.) Participation: From Tyranny to Transformation?, London: Zed Books, p3-24.

Jenkins, B. (2012) Mobilizing the Southern Agricultural Growth Corridor of Tanzania: A Case Study. Cambridge, MA: CSR Initative, Harvard Kennedy School.

Joala, R. (2016). Beira Corridor smallholders concerned about impact of agricultural investment on Mozambique's seed regimes [Online]. Available at: http://www.plaas.org.za/blog/beira-corridor-smallholders-concerned-aboutimpact-agricultural-investment-mozambique\%E2\%80\%99s-seed (Accessed: February 2018)

Kakonge, J.O. (2015) 'Environmental Impact Assessment: Why it Fails in Kenya', Pambazuka News, 7 October. Available at: www.pambazuka.org/land-environment/environmental-impact-assessment-why-it-fails-kenya (Accessed: February 2018) 
Khalil, A.C., Conforti, P., Ergin, I. and Gennari, P. (2017) Defining Small Scale Food Producers to Monitor Target 2.3 of the 2030 Agenda for Sustainable Development. FAO Statistics Division, Working Paper Series ESS/17-12, Rome: FAO.

Kibugi, R., Mwathane, I. and Makathimo, M. (2016) Large-Scale Land Acquisitions for Investment in Kenya: Is the Participation and Benefits of Affected Local Communities Meaningful and Equitable? A Case Study of the Situation in Lamu, Isiolo and Siaya Counties. Nairobi: Land Development and Governance Institute. Kenya: LDGl.

Mansuri, G. and Rao, V. (2013) Localizing Development: Does Participation Work?, Washington D.C.: World Bank.

Michels, A. (2011) 'Innovations in Democractic Governance: How does Citizen Participation Contribute to a Better Democracy?', International Review of Administrative Sciences,77(2), p275-293.

Monjane, B. (2017) 'Mozambique: Independent Examiners to Investigate JICA's Conduct over ProSavana'. Pambazuka News, 6 July. Available at: https://www.pambazuka.org/global-south/mozambique-independentexaminers-investigate-jica\%C2\%B4s-conduct-over-prosavana (Accessed: February 2018)

Mseteka, E. (2015) 'Zambia to be linked to Angola, DRC'. Zambia Daily Mail, 3 November. Available at: http:// www.daily-mail.co.zm/zambia-linked-angola-drc/ (Accessed: February 2018)

Nigeria NEXTT. (2017) Nigeria NEXTT [online]. Available at: http://www.nigerianextt.org/?page_id=334 (Accessed: February 2018)

No! To Landgrab. (2016) Prosavana's Communication Strategy and Its Impact: An Analysis of JICA's Disclosed And Leaked Documents, No! to Landgrab Japan Report. Available at: http://www.ajf.gr.jp/lang_ja/ activities/20171112/08_004.pdf (Accessed: February 2018)

Oxfam Novib. (2015) Multi-Stakeholder Engagement in Agribusiness Sectors: Oxfam's Experiences, Progress to Date and Reflections on the Future, Oxfam Novib Discussion Paper, The Hague: Oxfam Novib. Available at: www.oxfamnovib.nl/Redactie/Images/Wat\%20wij\%20doen/Projecten/Multi-Stakeholder_EngagementRapportweb.pdf (Accessed: February 2018)

Palacios-Lopez, A., Christiaensen, L. and Kilic, T. (2017) 'How Much of the Labor in African Agriculture is Provided by Women?', Food Policy, 67, p52-63.

Picard, F., Coulibaly, M. and Smaller, C. (2017) The Rise of Agricultural Growth Poles in Africa. Investment in Agriculture, IISD Policy Brief 6, Canada: International Institute for Sustainable Development.

Poole, N. (2017) Smallholder Agriculture and Market Participation. Rome and Rugby: Food and Agriculture Organization and Practical Action Publishing.

ProSavana. (2018) Communication Strategy of ProSavana [online]. Available at: http://www.prosavana.gov.mz/ portfolio-items/communication-strategy-of-prosavana/ (Accessed: February 2018)

Repcon Associates. (2017) Strategic Environmental Assessment for the LAPSSET Corridor Infrastructure Development Project: Draft Final Report. Kenya: The Repcon Centre.

SAGCOT. (2015). SAGCOT Partnership Principles [online]. Available at: http://www.sagcot.com/fileadmin/ documents/2015/SAGCOT_Partnership_Principles_15.08.14.pdf (Accessed: February 2018)

SAGCOT Centre. (2016) Annual Report 2016 [online]. Available at: http://www.sagcot.com/fileadmin/documents/ news/2017/SCL_Annual_Report_2016_JBA.pdf (Accessed: February 2018)

Saint Vil, L. (2011) 'Power to Producers - Building a Network of Dairy Enterprises Owned by Local Farmers' Groups in Haiti', in Wilson, D., Wilson, K. and Harvey, C. (eds.) Small Farmers, Big Change: Scaling Up Impact in Smallholder Agriculture. Rugby: Practical Action Publishing, p67-80.

Schut, M., Soares, N.C., van de Ven, G. and Slingerland, M. (2014) 'Multi-Actor Governance of Sustainable Biofuels in Developing Countries: The Case of Mozambique', Energy Policy, 65, p631-643.

Schlesinger, S. (2014) Brazilian Cooperation and Investment in Africa: The Case of ProSavana in Mozambique, TEMPTI Series EP 1/2014. Switzerland: IUCN. 
Sena, K. (2012) Lamu Port-South Sudan-Ethiopia Transport Corridor (LAPSSET) and Indigenous peoples in Kenya. Report on Expert Mission by a Member of the UN Permanent Forum on Indigenous Issues, International Working Group on Indigenous Affairs, Denmark: IWGIA.

Shankland, A. and Gonçalves, E. (2016) 'Imagining Agricultural Development in South-South Cooperation: The Contestation and Transformation of ProSAVANA', World Development, 81, p35-46.

Smalley, R. (2013) Plantations, Contract Farming and Commercial Farming Areas in Africa: A Comparative Review, Future Agricultures Working Paper 055, Brighton: Future Agricultures Consortium. Available at: http://www.fao. org/uploads/media/FAC_Working_Paper_055.pdf (Accessed: February 2018)

Smalley, R. (2017) Agricultural Growth Corridors on the Eastern Seaboard of Africa: An Overview, APRA Working Paper 1, Brighton: Future Agricultures Consortium. Available at: https://opendocs.ids.ac.uk/opendocs/ handle/20.500.12413/13564 (Accessed: February 2018)

Tanwir, M. and Safdar, T. (2013) 'The Rural Woman's Constraints to Participation in Rural Organizations', Journal of International Womens' Studies, 14(3), p210-229

USAID. (2013) Opportunity Assessment: Investment on the Lakaji Agricultural Growth Corridor. Nigeria: NEXTT. Available at: http://pdf.usaid.gov/pdf_docs/PA00KDHK.pdf (Accessed: February 2018)

USAID. (2017) USAID 2017 Trade Capacity Building Evaluation [Online]. Available at: http://pdf.usaid.gov/pdf_ docs/PA00MP8Q.pdf (Accessed: February 2018)

Venot, J-P. et al. (2017) 'Ideologies, Development Models and Irrigated Land Tenure: The Bagré Irrigation Project in Burkina Faso', Paper Presentation at the 2017 World Bank Conference on Land and Poverty, Washington DC, 20-24 March 2017.

Vogelsperger, R., Lakoussan, E. and Teshome, A. (2017) 2SCALE Partnership Governance. Accra: 2SCALE. Available at: https://www.2scale.org/upload/54d326_2SCALE_paper8.pdf (Accessed: February 2018)

WBCG. (2017) A Guide to the Walvis Bay Corridors. South Africa: Walvis Bay Corridor Group

West, J. and Haug, R. (2017) 'Polarised Narratives and Complex Realities in Tanzania's Southern Agricultural Growth Corridor', Development in Practice, 27(4), p418-431.

Woodhill, J. (2016) Inclusive Agribusiness: The State of Play. Background Working Paper Prepared for the Global Donor Platform for Rural Development. Available at: https://tapipedia.org/sites/default/files/inclusive_ agribusiness_working_paper.pdf (Accessed February 2018)

World Bank. (2011) Burkina Faso - Bagre Growth Pole Project. Project Information Document, Document no. AB5668, Washington DC: World Bank. Available at: http://documents.worldbank.org/curated/ en/774001468019806803/pdf/ProjectOInform1cument1ConceptOStage.pdf (Accessed February 2018)

World Bank. (2016a) International Development Association Project Appraisal Document on a Proposed Credit in the Amount of (SDR 50.8) Million (US\$ 70 Million Equivalent) to the United Republic of Tanzania for a Southern Agricultural Growth Corridor of Tanzania (SAGCOT) Investment Project, Report no. PAD345, Washington DC: World Bank. Available at: http://documents.worldbank.org/curated/en/621921468190165214/pdf/PAD345-PADP125728-IDA-R2016-0016-1-OUO-9.pdf. (Accessed: February 2018)

World Bank. (2016b) Proposed Project Restructuring of The Mozambique Sustainable Irrigation Development Project, Report no: RES21715, Washington DC: World Bank. Accessed at: http://documents.worldbank.org/ curated/en/770281468053057870/pdf/Restructuring-Paper-2-EGP-April-12.pdf (Accessed: February 2018)

World Bank. (2017) Implementation Status Report: Sequence 13. December 2017. Washington DC: World Bank 


\section{ENDNOTES}

i. In this paper, 'upstream' and 'downstream' refer to activities and actors in agricultural and agribusiness supply chains, where upstream refers to producers and their input suppliers, and downstream refers to agricommodity processors, traders and food manufacturers.

ii. Women's share of labour in livestock farming was not estimated by the authors.

iii. There is no consensus on terminology, but in this paper, unless specified, we use the term 'smallholder' to refer to small-scale crop farmers, small-scale farmers with livestock, pastoralists and agro-pastoralists. For a discussion of the factors that define small scale, including size of holding and animal numbers, use of paid labour and extent of market integration, see Khalil et al. (2017). We also refer to people who run smallscale agribusinesses, which are active in agricultural supply chains up- or down-stream. It is understood that any of these actors may be women, who are highlighted separately in this paper because of concerns that, while acknowledging other aspects of difference such as class or age, women are at particular risk of marginalisation and exclusion.

iv. "In the nucleus-outgrowers model, contract farming is combined with a plantation, so that contracted smallholders, or 'outgrowers', complement production on a central estate” (Smalley, 2013:10).

v. We do not include in this list any activities that were offered to communities in the Bagre Growth Pole as compensation for resettlement (see World Bank, 2017). 
Smalley, R., Sulle, E., Chome, N., Duarte, A. and Gonçalves, E. (2021) Agricultural Investment Corridors in Africa: Challenges and Opportunities for Strengthening Smallholder and Women's Participation, APRA Working Paper 62, Brighton: Future Agricultures Consortium

\section{(cc) BY-NC-ND}

This is an Open Access report distributed under the terms of the Attribution-Non Commercial-No Derivs 4.0 Unported (CC BY-NC-ND 4.0) Attribution - You must give appropriate credit, provide a link to the license, and indicate if changes were made. You may do so in any reasonable manner, but not in any way that suggests the licensor endorses you or your use. NonCommercial — You may not use the material for commercial purposes. NoDerivatives - If you remix, transform, or build upon the material, you may not distribute the modified material. You are free to: Share - copy and redistribute the material in any medium or format.

https://creativecommons.org/licenses/by-nc-nd/4.0/legalcode

If you use the work, we ask that you reference the APRA website (www.future-agricultures.org/apra/) and send a copy of the work or a link to its use online to the following address for our archive: APRA, Future Agricultures Consortium, University of Sussex, Brighton BN1 9RE, UK (apra@ids.ac.uk)

All APRA Working Papers go through a review process before publication.

\section{Cc. Creative}

\section{DO YOU HAVE COMMENTS ON THIS PAPER?}

We would welcome your feedback on this working paper!

To provide brief comments, please follow this link to our short APRA Working Paper Feedback form: https://goo.gl/forms/1iVnXhhrIGesfR9

Agricultural Policy Research in Africa (APRA) is a programme of the Future Agricultures Consortium (FAC) which is generating new evidence and policy-relevant insights on more inclusive pathways to agricultural commercialisation in sub-Saharan Africa. APRA is funded with UK aid from the UK Foreign, Commonwealth \& Development Office (FCDO) and will run from 2016-2022.

The APRA Directorate is based at the Institute of Development Studies (IDS), UK (www.ids.ac.uk), with regional hubs at the Centre for African Bio-Entrepreneurship (CABE), Kenya, the Institute for Poverty, Land and Agrarian Studies (PLAAS), South Africa, and the University of Ghana, Legon. It builds on more than a decade of research and policy engagement work by the Future Agricultures Consortium (www.future-agricultures.org) and involves more than 100 researchers and communications professionals in Africa, UK, Sweden and USA. 